\title{
KNOWLEDGE MANAGEMENT PROCESS, KNOWLEDGE SHARING, AND TEACHER LITERACY SKILLS AT VOCATIONAL HIGH SCHOOLS
}

\author{
A. Sobandi *, Edi Suryadi, M. Arief Ramdhany, Rasto Rasto \\ Universitas Pendidikan Indonesia, Bandung, Indonesia \\ *e-mail: ade@upi.edu
}

\begin{abstract}
The development of students in mastering the skills of the 21st century is certainly inseparable from the role of educators in understanding the various skills and the use of digital technology associated with it, supported by knowledge management process and knowledge sharing. The purpose of this study is to analyze the effect of the knowledge management process and knowledge sharing on teacher literacy skills at State Vocational High Schools (VHSs) in West Java. To collect data, a questionnaire was used. This research used a quantitative approach through descriptive and verification research. Based on the characteristics of the variables, a survey using a 7-point Likert scale questionnaire was conducted. This research was purposely administered to 162 teachers from 54 VHSs at 27 cities/regencies in West Java. The Partial Least Square Structural Path-Modeling (PLS-PM) was used to test the hypotheses. The research outcomes revealed that the knowledge management processes and knowledge sharing have a positive effect on teacher literacy skills. Information literacy is important for building literacy skills, but achievement is relatively low. The teacher needs to align these skills with more appropriate directions so that teachers' literacy skills in the learning process can be more effective.
\end{abstract}

Keywords: knowledge management, knowledge sharing, literacy.

\section{PROSES MANAJEMEN PENGETAHUAN, BERBAGI PENGETAHUAN, DAN KETERAMPILAN LITERASI GURU DI SEKOLAH MENENGAH KEJURUAN}

\begin{abstract}
Abstrak: Perkembangan peserta didik dalam penguasaan keterampilan abad 21 tentunya tidak terlepas dari peran pendidik dalam memahami berbagai keterampilan dan pemanfaatan teknologi digital terkait, didukung oleh implementasi manajemen pengetahuan dan berbagai pengetahuan. Penelitian ini bertujuan untuk menganalisis pengaruh proses manajemen pengetahuan terhadap keterampilan literasi guru pada SMK Negeri di Jawa Barat yang dimediasi oleh berbagi pengetahuan. Pengumpulan data menggunakan kuesioner. Penelitian ini menggunakan pendekatan kuantitatif, melalui penelitian deskriptif dan verifikatif. Berdasarkan karakteristik variabel, penelitian ini dilakukan dengan survei (7 rating scale). Penelitian ini dilakukan secara purposif terhadap 162 guru dari 54 SMK di 27 kota/kabupaten di Jawa Barat. Partial Least Square Structural Path-Modeling (PLS-PM) digunakan untuk menguji hipotesis. Hasil penelitian mengungkapkan bahwa manajemen pengetahuan dan berbagi pengetahuan berpengaruh positif terhadap keterampilan literasi guru. Literasi informasi penting untuk membangun keterampilan literasi, namun pencapaiannya relatif rendah. Guru perlu menyelaraskan keterampilan tersebut dengan arahan yang lebih tepat agar keterampilan literasi guru dalam proses pembelajaran dapat lebih efektif.
\end{abstract}

Kata Kunci: manajemen pengetahuan, berbagi pengetahuan, literasi.

\section{INTRODUCTION}

Education and human resources are the most important determinants of national development in this globalization and digital era (Blanchard \& Olney, 2017). Education is increasingly expected to promote standardized development goals and economic competitiveness in the global arena (Buckner, 2017). All countries in this globalization era are developing the education because educational institutions, from basic education to higher education, have a very important role as agents of change and transformation toward better development of a country, including Indonesia.

At school, teacher plays an important role in planning, implementing, and evaluating the learning process. An effective learning process can enhance and produce graduates to respond to global challenges (Trilling \& Fadel, 2009). The creativity, capacity, competence, innovation, and attitude of professional teachers are needed to make this happen. To master knowledge compe- 
tence, the learning process is not enough. Other competencies are also necessary for the creation of an effective learning process. The learning process must take place in a combination of knowledge about the subject matter and knowledge to deliver the material properly and appropriately in line with pedagogical knowledge, supported by suitable learning media and technology (Scheiner, Montes, Godino, Carrillo, \& Pino-Fan, 2019).

The development of information and telecommunications technology (ICT) in the $21^{\text {st }}$ century is driving changes in all sectors, including the education sector. In education and learning, digital ICT simultaneously demands, reflects, and builds the skills and knowledge of teachers in various learning processes, both using old and new learning methods (Griffin \& Care, 2015). Teachers need to master the integration of knowledge and skills related to the content, pedagogy, and technology to be able to transfer them to students. There are 12 skills that students need to master in the information age, which is called " $21^{\text {st }}$ century skills", including information literacy, media literacy, and technology literacy, which must go hand in hand with other skills (learning skills and life skills) (Voogt \& Roblin, 2010). To teach these skills to students, the teacher must first have knowledge of these skills.

Teacher literacy skills can be heavily influenced by various factors, including personal literacy competence and the external environment such as knowledge management process and knowledge sharing. Literacy skills (information, media, and technology) require students and educators to realize the importance of knowledge sharing and knowledge management process (Alshehri \& Cumming, 2020). Mastering the abilities of operating information and communication technology is one of the competencies of a professional teacher, including teachers of Vocational High Schools (VHSs). This skills and experience must be supplemented with functional digital literacy (Rusydiyah, Purwati, \& Prabowo, 2020). Various issues have developed, including teachers who are not yet maximizing the use of technology in the classroom. Many teachers teach in a traditional manner. To effectively deploy the literacy skills integrated with learning of information technology, actions to encourage the teachers are required (Rahim, Suherman \& Murtiani, 2019). The knowledge management model and knowledge sharing can enhance the digital literacy abilities (DLA) of teachers (Silamut \& Petsangsri, 2020).

The emergence of knowledge management $(\mathrm{KM})$ as a practical discipline is related to the fact that knowledge is an important source for organizations to develop and maintain sustainable competitive advantage (Easa, 2012). The idea of knowledge management has attracted many researchers and has been studied theoretically and practically (Bose, 2002). The importance of this knowledge has encouraged organizations to pay more attention to how to manage the knowledge effectively (Choi, Poon \& Davis, 2008).

Knowledge can be organizational or personal (Fuller \& Unwin, 2004). Organizational knowledge is the ability of members of an organization to make distinctions in the course of their job, in particular concrete circumstances, by enacting sets of generalizations whose application is based on historically established collective understandings. Meanwhile, personal knowledge is an individual's ability to make distinctions within an area of action based on an understanding of context or theory, or both (Dulipovici \& Baskerville, 2007).

In organizations, knowledge can also be internal or external (Frenz \& Ietto-Gillies, 2009). Internal knowledge is obtained from internal sources such as employees, the R\&D department, the sales department, and the production department. External knowledge is obtained from external institutions such as experts, customers, suppliers, and other organizations/institutions. With various types of knowledge, all of these types are rooted and reside in the human mind, both tacit and explicit. Tacit knowledge refers to that the personal and context-specific are difficult to define and explain, and the explicit knowledge may be expressed in a formal, systematic manner (Nonaka \& Takeuchi, 1995). Concerning the characteristics of tacit and explicit knowledge, the two forms of knowledge can be considered separate and distinct.

The scope of knowledge management $(\mathrm{KM})$ is not something that can be generally accepted. $\mathrm{KM}$ is defined as the coordination and exploitation of organizational knowledge resources in order to produce value and competitive advantage (Drucker, 2007). Nevertheless, the scope of knowledge management can be limited to lessons learned and techniques used to manage things that are already known. Furthermore, KM is defined as the process of acquiring, organizing, sustaining, applying, sharing, and renewing both tacit and explicit knowledge of employees to 
improve organizational performance and create value through a systematically and organizationally specified process for acquiring, organizing, sustaining, applying, sharing, and renewing both tacit and explicit knowledge of employees to enhance organizational performance and create value (Davenport \& Prusak, 1998).

Measurement and dimensions of knowledge management refer to the model in an organizational context: acquisition of knowledge, storage of knowledge, distribution of knowledge, and use of knowledge (Gonzalez \& Martins, 2017). In the study of secondary education, in addition to being an element of forming a sustainable competitive advantage, knowledge is also a value for these educational institutions, so that the perspective of knowledge in educational institutions implies the exploration of knowledge internally and externally both as a resource and as an output from the process of developing knowledge management that is carried out by the school, with the teacher as the main agent. By using knowledge management, teachers are encouraged to become human capital, so that the recognition of the quality of a teacher is not only based on seniority but on the extent to which the teacher is part of the use of knowledge management in schools.

Today, organizations are increasingly aware of the importance of knowledge sharing (KS) among members of the organization. Employees and managers also seek, test, and use various proactive interventions to facilitate this knowledge sharing. Knowledge sharing is supported by a variety of different objectives, i.e. acquire knowledge, reuse knowledge, and develop new knowledge (Zimmerman, 2008). Advancement of ICT has enabled support to achieve these goals. Based on the theory, knowledge sharing can lead to real benefits in certain situations. This success certainly depends on many factors, such as additional advantages for an individual in sharing knowledge with other individuals, collective involvement in organizations, and accuracy of the application of ICT. In the end, the important factor in the success of knowledge sharing is the level of application in daily operations in an organization. If this knowledge sharing process can be institutionalized, then all those involved in the organization are assumed to have made knowledge sharing an important part of their daily work routines.

Knowledge sharing (KS) is the most important part of knowledge management (KM)
(Koenig \& Srikantaiah, 2004). In this case, managing and sharing knowledge cannot be separated. KM would be meaningless without $\mathrm{KS}$. KS in $\mathrm{KM}$ is also influenced by various factors, including (a) leadership, (b) culture, (c) structure, roles and responsibilities, (d) information technology infrastructure, and (e) measurement.

KS creates opportunities to maximize an organization's ability to meet those needs and produce solutions and efficiencies that provide competitive advantages for businesses (Reid, 2003). In other words, KS is a culture of social interaction, which involves the exchange of employees' knowledge, experience, and skills through an entire department or organization (Lin, 2007). As previously stated, KS is closely related to the application of KM. While conventional knowledge management focused on technology or the capacity to design systems that efficiently handles and use knowledge, the new model of knowledge management includes people and activities. Its goal is to create an atmosphere in which power equals information sharing rather than knowledge retention (AlAlawi, Al-Marzooqi \& Mohammed 2007).

Thus, KS is not just technology, but rather is a new $\mathrm{KM}$ model that involves humans and action. It consists of some understandings related to giving employees access to relevant information so that they can then build and use knowledge networks within the organization (Hoegl, Parboteeah \& Munson, 2003). Moreover, KS arises at the individual and organizational levels. For individual employees, KS can be in the form of speaking to coworkers to get things done better, faster, and more efficiently. In KS, organizations need to make efforts to capture, organize, reuse, and transfer experience-based knowledge that is in the organization and make that knowledge available to other parties. Some previous studies have shown the importance of KS because it allows organizations to improve their innovation capabilities and business performance while reducing redundant learning efforts (Calantone, Tamer \& Yushan, 2002).

The first indicator to measure KS is assessment, namely assessment and direct perception of members of the organization related to the level of implementation of $\mathrm{KS}$ in the organization, whether it is excellent, good, or poor. The next indicator is KS techniques (Davenport \& Prusak, 1998), including collaboration and teamwork, training (either new or existing staff), formal and informal discussion, utilizing knowledge sharing 
tools (e.g. e-mails, document management systems, groupware, intranet, etc.), communication networks (internet, intranet, and extranet), chatting during break time, brainstorming, workshops, seminars, conferences, focus groups discussion (FGD), and quality circle. Another indicator of knowledge sharing is teamwork or collaboration in carrying out routine tasks (Goh, 2002). Finally, the willingness is one of the indicators of KS with colleagues or other parties outside the organization.

The development of students in mastering the skills of the $21^{\text {st }}$ century is certainly inseparable from the role of educators in understanding the various skills and the use of digital technology associated with it. By understanding $21^{\text {st }}$ century skills and utilizing digital technology in learning, educators can implement these demands for the benefit of future students. The purpose of this study is to analyze the effect of the knowledge management (KM) process and knowledge sharing (KS) on teacher literacy skills at State Vocational High Schools (VHSs) in West Java.

\section{METHODS}

This research used a quantitative approach through descriptive and verification research. This research was administered to 54 VHSs at 27 cities/regencies in West Java. We purposely selected two vocational schools from each city/regency, because each represented one public school and one private school. From the total of 54 VHSs, we asked three teachers from each VHS, so the total number of 162 teachers participated in this survey. This study was conducted using a survey by distributing a 7point Likert scale questionnaire to the teachers via Google Form. Before distributing the questionnaire, the validity and reliability of the instrument had been tested.

The operationalization of these variables can be explained as follows. First, Knowledge Management Process (KMP) is an exogenous latent variable, measured by acquisition, storage, distribution, and use of knowledge. The measurements were modified form (Zimmerman, 2008; Gonzalez \& Martins, 2017; Davenport \& Prusak, 1998). The questionnaire measures how the teachers acquire, store, distribute, and use the knowledge, with 12 items to measure this construct.

Second, Knowledge Sharing (KS) is an endogenous latent variable and also mediating variable, measured by assessment, technical, collaboration, and willingness. The measurements were modified form (Lin, 2007; Koenig \& Srikantaiah, 2004; Goh, 2002; Davenport \& Prusak, 1998). The questionnaire measures how the teachers experience regarding the assessment, the technical, the collaboration, and the willingness in sharing the knowledge, with 12 items to measure this construct.

Third, Teacher Literacy Skills is an endogenous latent variable, measured by literacy skills on information, media, and technology. The measurements were modified form those developed by (Dinçer, 2018; Voogt \& Roblin, 2010). The questionnaire measures the ability of teacher to deal with the literacy of information, media, and technology, with 12 items to measure this construct.

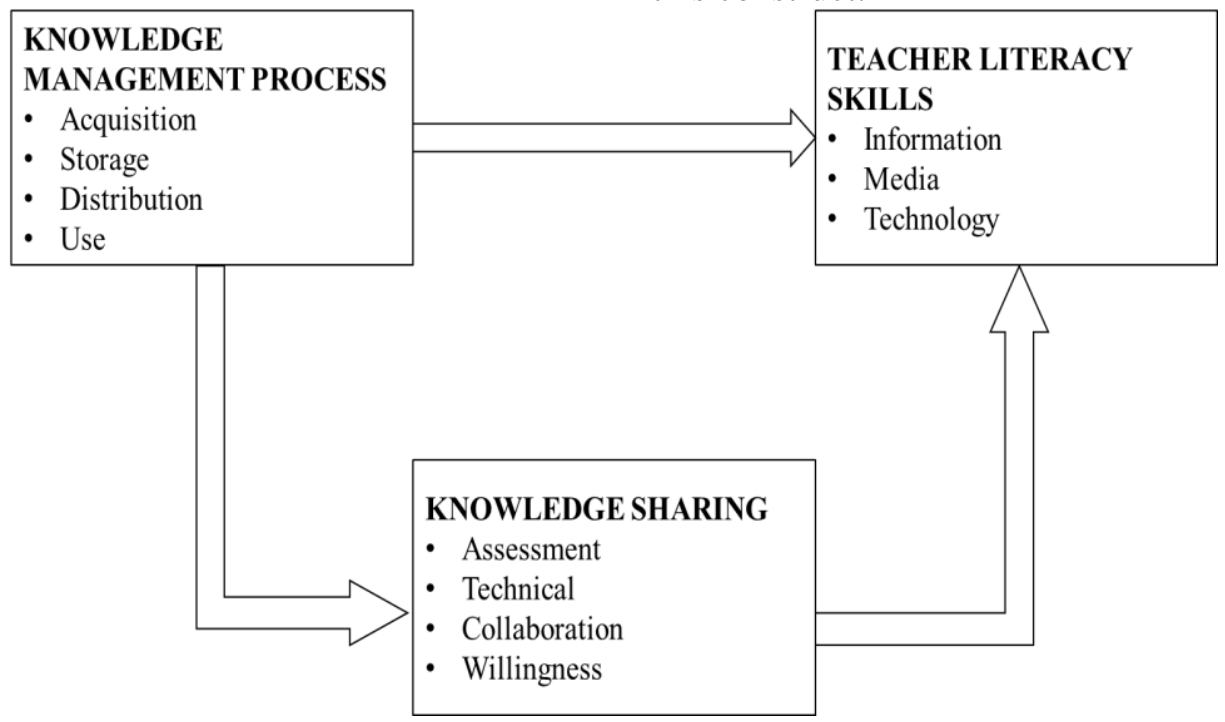

Figure 1. Research Model 
The data were analyzed using descriptive analysis and Partial Least Square Path Modeling (PLS-PM) analysis. Descriptive analysis is a statistic used to analyze data by describing the data that has been collected as it is without intending to make generally accepted conclusions or generalizations. Descriptive statistics used are the average achievement values (mean) of each indicator, dimension, and variable, the value of which can be grouped in certain categories (Manfredo, Vaske \& Teel, 2003).

The determination of this category is based on a comparison of the maximum ideal average score minus the ideal average score, so that values can be divided into 4 quartiles (Low $=1.0$ to 2.4 , Fairly Low $=2.5$ to 4.4., Fairly High 4.5 to 5.4, and High $=5.5$ to 7.0) (Blumberg, Cooper \& Schindler, 2014). The research model is presented in Figure 1.

PLS-PM analysis, which combines measurement models and structural models, is used to test the hypothesis. The link between a concept and indicators/dimensions is investigated using the measuring model (also called manifest variables). The following are some of the results of this measuring model calculations (Henseler, 2017): (1) Construct reliability using DijkstraHenseler's rho ( $\square$ A), composite reliability ( $\square$ C), and Cronbach's alpha ( $\square$ ); (2) Convergent reliability using the measurement of Average Variance Extracted (AVE); (3) Discriminant validity using the Fornell-Larcker criterion and the Heterotrait-monotrait ratio of correlations (HTMT); (4) Measurement indicators using factor loadings and cross-loadings.

The structural model deals with estimating the relationship between one latent variable and one or several other variables. The determination of structural models usually includes the following calculations: (1) Inter-construct correlations; (2) coefficient of determination $\left(\mathrm{R}^{2}\right)$; (3) Path coefficients, Indirect effects, and total effects; and (4) Effect size (Cohen's f ${ }^{2}$ ).

\section{FINDINGS AND DISCUSSION}

\section{Findings}

The descriptive analysis shows average performance scores, standard deviations, and categories. Descriptive analysis results for each construct can be presented in Table 1. Based on Table 1, the Knowledge Management Process (KMP) of the teachers is in a fairly high category (mean=4.91 from ideal of 7.00). It implies that teachers have adequate knowledge related to the acquisition, storage, distribution, and use. In this sense, the indicator of storage is the highest compared to other indicators in this construct (mean=5.22 from ideal of 7.00). Nevertheless, the standard deviation is also high which means there is high variability in storing knowledge among the teachers. It means that some teachers are good in storing their knowledge, while the others are not too serious in this activity. The use of knowledge is the lowest compared to other indicators, which means several teachers are still experiencing some specific difficulties in using knowledge adequately.

Knowledge Sharing (KS) of the teachers is also in fairly high category (mean=5.35). It indicates that the teachers have also adequate levels of assessment, technical, collaboration, and willingness to share knowledge with their colleagues and the students. The willingness to share knowledge is the highest, while the assessment of knowledge sharing is the lowest among those indicators.

Teacher Literacy Skills (TLC) is in a fairly high category (mean=4.13). Media literacy is the highest indicator of these teacher literacy skills, followed by technology literacy. It means that the teachers are fully aware of the kinds of media that they use. The information literacy of the teacher, however, is the lowest indicator with the largest variability. This condition shows that teachers often get lost in the flow of unimportant and useless information.

To test the hypothesis, PLS analysis is used, through the measurement model and the structural model. PLS calculations in this study use the ADANCO program version 2.1.1. The overall model in this study is presented in Figure 2.

Construct reliability, convergent reliability, discriminant validity, and factor loadings are used to calculate the measurement model. Calculation of construct reliability using Dijkstra-Henseler's rho ( $\square$ A), composite reliability $\square \square$ C), and Cronbach's alpha ( $\square$ ) can be presented in Table 2. The table shows that all constructs have a value of $>0.7$ so that the constructs of Knowledge Management Process, Knowledge Sharing, and Teacher Literacy Skills are reliable and support a good model. Convergent reliability calculation uses the measurement of Average Variance Extracted (AVE) which is usually interpreted as a measure of unidimensionality. Reflective constructs show good unidimensionality if the AVE value is more than 0.5 (Fornell \& Larcker, 1981). The results of convergent reliability calculations using AVE 
can be presented in Table 3. The calculation results show that the AVE value for each construct is more than .5 so that it can be stated that all constructs have good unidimensionality.

Fornell-Larcker criterion states that AVE of a construct should be higher than the value of squared correlations with other constructs in the model. The heterotrait-monotrait ratio of correlations (HTMT) measures the discriminant validity of all factors. HTMT values should be lower than 0.9 or 0.85 . The results of discriminant validity calculations using the Fornell-Larcker criterion and HTMT can be presented in Table 4.

The calculation results show that the HTMT value is below 0.9 and in the FornellLarcker Criterion, it can be seen that the AVE value (which is marked in bold) is higher than the value of each of its square correlation. This discriminant validity shows that each construct studied does have different characteristics in the concept. In other words, a construct has a different concept from another construct.

Factor loadings are slopes of a simple regression of an indicator with its construct. The loading matrix factor can be presented in Table 5 . The coefficient of determination $\left(\mathrm{R}^{2}\right)$ quantifies how much of an endogenous variables variance can be explained by independent variables. Based on these findings, it can be concluded that the KMP accounts for 42.4 percent of the variance in the construct of KS and that the KMP and KS account for 37.0 percent of the variance in the construct of Teacher Literacy Skills. Overall, the results can be observed in Table 6,7 and 8 .

Table 1. Descriptive Analysis

\begin{tabular}{llll}
\hline Indicators & Mean & Std. Dev. & Category \\
\hline Acquisition & 5.12 & 1.02 & Fairly High \\
Storage & 5.22 & 1.17 & Fairly High \\
Distribution & 5.14 & 0.92 & Fairly High \\
Use & 4.13 & 1.13 & Fairly High \\
Knowledge Management Process (KMP) & 4.91 & 1.15 & Fairly High \\
\hline Assessment & 5.26 & 1.16 & Fairly High \\
Technical & 5.30 & 1.00 & Fairly High \\
Collaboration & 5.29 & 1.01 & Fairly High \\
Willingness & 5.54 & 1.00 & High \\
Knowledge Sharing (KS) & 5.35 & 1.00 & Fairly High \\
\hline Information Literacy & 3.98 & 1.16 & Fairly Low \\
Media Literacy & 4.24 & 1.00 & Fairly High \\
Technology Literacy & 4.16 & 1.01 & Fairly High \\
Teacher Literacy Skills (TLC) & 4.13 & 1.06 & Fairly High \\
\hline
\end{tabular}

Table 2. Construct Reliability

\begin{tabular}{llll}
\hline Construct & Dijkstra-Henseler's rho $\left(\boldsymbol{\rho}_{\mathbf{A}}\right)$ & Jöreskog's rho $\left(\boldsymbol{\rho}_{\mathbf{c}}\right)$ & Cronbach's alpha( $\boldsymbol{\alpha})$ \\
\hline KMP & 0.787 & 0.861 & 0.784 \\
KS & 0.852 & 0.898 & 0.848 \\
TLS & 0.950 & 0.967 & 0.949 \\
\hline
\end{tabular}

Table 3. Convergent Reliability

\begin{tabular}{ll} 
Construct & Average variance extracted (AVE) \\
\hline KMP & 0.607 \\
KS & 0.687 \\
TLS & 0.908 \\
\hline
\end{tabular}

Table 4. Discriminant Validity

Heterotrait-Monotrait Ratio of Correlations (HTMT)

\begin{tabular}{lccc}
\hline Construct & KMP & KS & TLS \\
\hline KMP & & & \\
KS & 0.848 & & \\
TLS & 0.648 & 0.621 & \\
\hline Fornell-Larcker Criterion & & & \\
\hline KMP & $\mathbf{0 . 6 0 7}$ & & \\
KS & 0.490 & $\mathbf{0 . 6 8 7}$ & \\
TLS & 0.315 & 0.313 & $\mathbf{0 . 9 0 8}$ \\
\hline
\end{tabular}

Squared correlations; AVE in the diagonal. 


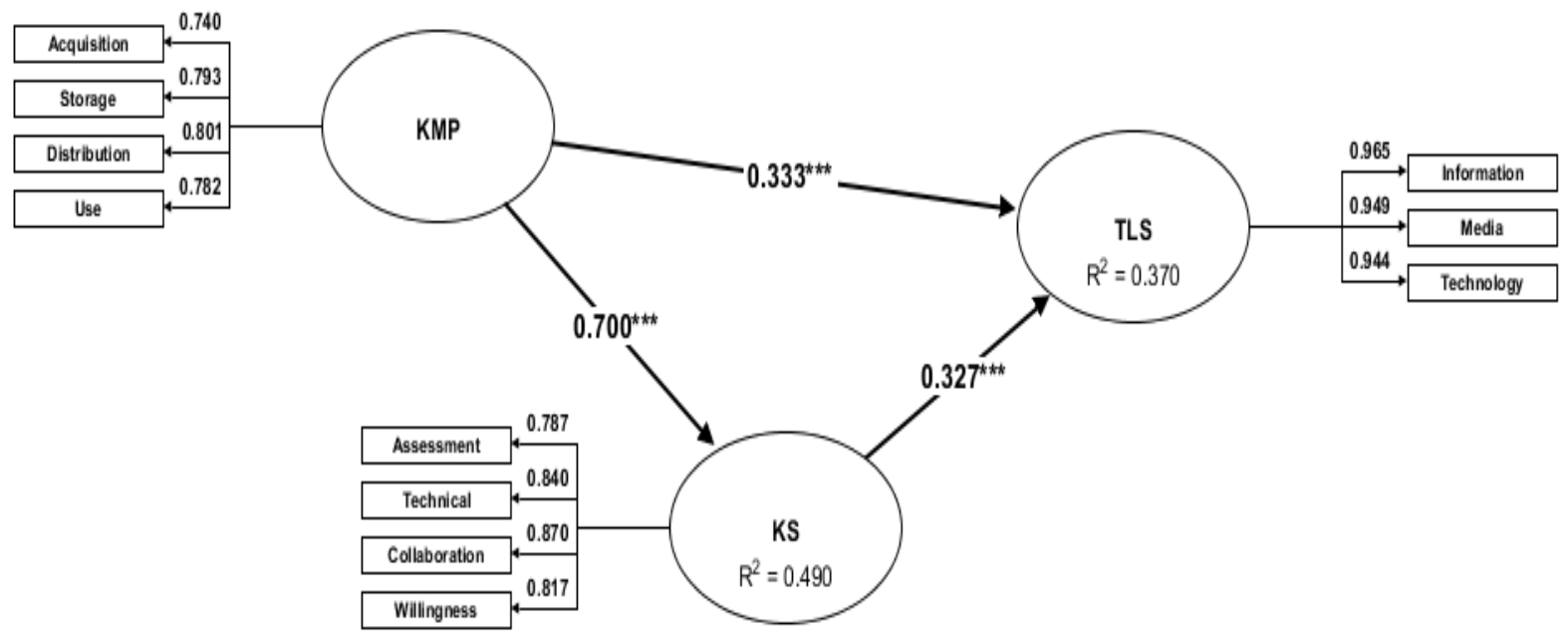

Figure 2. Overall Model

Table 5. Factor Loading

\begin{tabular}{lccc}
\hline Indicator & KMP & KS & TLS \\
\hline Acquisition & 0.740 & & \\
Storage & 0.793 & & \\
Distribution & 0.801 & & \\
Use & 0.782 & & \\
\hline Assessment & & 0.787 & \\
Technical & & 0.840 & \\
Collaboration & & 0.870 & \\
Willingness & & & 0.817 \\
\hline Information & & & \\
Media & & & 0.965 \\
Technology & & & 0.949 \\
\hline
\end{tabular}

Table 6. Inter-construct Correlation

\begin{tabular}{llll}
\hline Construct & KMP & KS & TLS \\
\hline KMP & 1.000 & & \\
KS & 0.700 & 1.000 & \\
TLS & 0.561 & 0.560 & 1.000 \\
\hline
\end{tabular}

Table 7. Coefficient of Determination $\left(\mathbf{R}^{2}\right)$

\begin{tabular}{lll}
\hline Construct & Coefficient of determination $\left(\mathrm{R}^{2}\right)$ & Adjusted $\mathrm{R}^{2}$ \\
\hline KS & 0.490 & 0.487 \\
TLS & 0.370 & 0.362 \\
\hline
\end{tabular}

Table 8. Effect Overview

\begin{tabular}{llllll}
\hline Effect & Beta & Indirect effects & Total effect & p-value & Cohen's f $^{2}$ \\
\hline KMP $\rightarrow$ KS & 0.700 & & 0.700 & 0.000 & 0.960 \\
KMP $\rightarrow$ TLS & 0.333 & 0.229 & 0.561 & 0.000 & 0.089 \\
KS $\rightarrow$ TLS & 0.327 & & 0.327 & 0.000 & 0.086 \\
\hline
\end{tabular}

Path coefficients are standardized regression coefficients (beta values). This path coefficient measures the direct effect of an independent variable on a dependent variable. This path coefficient can be interpreted as an increase in the dependent variable if the independent variable rises to one standard deviation and all other independent variables in the equation remain constant. Based on the results of bootstrapping, it was found that each path of the exogenous to the endogenous variable has a p-value below 0.05 which indicates that all paths are significant so that all hypotheses are accepted. The hypotheses testing shows that KMP has a significant effect on KS, KMP has a significant effect on TLS, and KS has a significant effect on TLS. In this model, KS functions as a mediating variable for KMP and TLS. The effective knowledge management process will eventually support knowledge sharing among the teachers. Consequently, the 
prevail dissemination of knowledge sharing will sharpen the teacher literacy skills.

\section{Discussion}

The teachers of VHS must engage in Knowledge Management Process (KMP) to improve their professional development. This research found that the aspect of KMP distribution among teachers has the biggest contribution to KMP, followed by the aspect of storage and aspect of use. Meanwhile, the aspect of the acquisition is the lowest among them. In Knowledge Sharing (KS), the biggest contribution is the aspect of collaboration, followed by technical aspect, and willingness to share the knowledge. Meanwhile, some teachers believed that the aspect of KS assessment is still poor. In Teacher Literacy Skills (TLC), we found that the aspect of information dominates the literacy skills, followed by the aspect of media. Nevertheless, the aspect of technology is still low compared to other aspects.

From the standpoint of schools, a school knowledge management framework can facilitate teacher learning and professional development (Zhao, 2010). Developing a learning school and organizational learning culture, establishing a teacher knowledge management system of teacher professional development, encouraging team learning, teaching cooperation, and knowledge sharing are some of the knowledge management strategies to improve teacher professional development. It also established a performance assessment mechanism of knowledge applications and development.

Teachers may also utilize online didactic tools to develop knowledge management (KM) processes (Biasutti \& EL-Deghaidy, 2012) and fulfill the needs of students while engaging in interdisciplinary initiatives. As part of a broader and deeper view of the school as a learning organization, a strong commitment may assist existing teachers in developing knowledge management and sustainable innovation systems within and across schools (Hogan \& Gopinathan, 2008). To put KM into practice, it is critical to first understand how teachers think about it. From the teachers' perspective, knowledge sharing, people, culture, and knowledge storage with IT assistance are all vital. Most teachers recognize that knowledge management may help them improve their practice, but it requires support from a variety of sources, including people, culture, information technology, and school management (Chu, Wang \& Yuen, 2011).
In the context of school education, knowledge management strategies, or the process of acquiring and distributing organizational knowledge, can improve intellectual capital (Cheng, 2017). The process may optimize the acquisition, storage, distribution, and use of relevant professional knowledge of the teachers. In terms of practical ramifications, it was advised that all teachers and headmasters attend clinical training and seminars on knowledge management to better grasp the knowledge management processes that could improve school teaching quality (Supermane, 2019). Trust, organizational rewards, organizational culture, KM system quality, openness in communication, and member interactive communication all influenced KS in schools, and KS greatly influenced collaboration (Tan \& Noor, 2013).

Improving the teachers' literacy skills is important because students today live in a world where reading and writing are commonplace, whether through digital media or conventional literature. The challenge for teachers is to connect the literacy skills that students develop in their social environment with the literacy environment of the school (Considine, Horton \& Moorman, 2009). Technology skills and literacy applications, such as the ability to gather, organize, manage, analyze, and communicate information, must be addressed in classrooms. Teachers must have a strong concept of what it means to be literate in the twenty-first century as they incorporate these skills into classroom instruction (Pilgrim \& Martinez, 2013).

In today's information-driven society, information literacy is a crucial skill for survival (Burke, 2010). Schools must teach students how to become effective users of information through information literacy skills to prepare them for success in the real world. Technological advancements will undoubtedly continue; as a result, people must adapt and embrace these developments or risk being left behind.

The literacy skills, especially the media literacy, must be supported by several competencies: access, analysis and evaluation, creation, reflection, and action/agency (McDougall, Zezulkova, van Driel \& Sternadel, 2018). These skills work together to encourage students' active participation in learning by allowing them to consume and create media messages. They can be helped in elementary and secondary schools by including media literacy into the curriculum and implementing particular teaching and learning strategies that address disinformation in 
dedicated classrooms. Contextual variables such as relevant teacher education, a supportive school environment, and local partnerships all help to foster media literacy competencies. The teachers' literacy skills may enhance the critical thinking skills needed by teachers in developing the learning materials (Suryandari et al., 2018).

Overall, this study confirms the findings of (Hoegl, Parboteeah, \& Munson 2003; Goh, 2002) (Davenport \& Prusak, 1998; Calantone, Tamer \& Yushan, 2002) related to the importance of knowledge management in increasing knowledge sharing and in turn developing teacher literacy skills. Effective knowledge management process at schools can optimize the teacher knowledge sharing activities and finally the literacy skills of teachers will be effective.

\section{CONCLUSION}

This research reveals the effect of knowledge management (KM) on teacher literacy skills mediated by knowledge sharing (KS) at Vocational High Schools in West Java. The effect of each exogenous on the endogenous variable is significant. Knowledge sharing may function as a mediating variable for the knowledge management process and teacher literacy skills. To optimize the KM process, the teachers must focus on the aspect of distribution that can enhance the collaboration in KS, and in turn, can improve information literacy. The information literacy is important for building literacy skills, but achievement is relatively low. The teacher needs to make some efforts to align these skills with more appropriate directions. With a more precise direction of literacy skills, it is expected that teacher literacy skills in the learning process can be more effective. Many teachers have some difficulties in acquiring the new knowledge from external resources so that they need more initiatives in updating the new knowledge. The schools may provide financial and non-financial rewards to the teachers who are eager to acquire the new relevant knowledge. Besides that, the schools may assign the teacher to follow the Training of Trainer of the relevant knowledge that fulfills the teachers with competency certification or license. To improve knowledge sharing, the teachers have to adjust their perception about the KS implementation so that their role perception will be accurate. The schools can assist the teachers to collaborate with internal and external parties by encouraging peerteaching and collaborative learning. The ability of teachers to adapt to the new technology is still low so the teachers have to get used to the technology acceptance that may interest the teachers.

\section{REFERENCES}

Al-Alawi, A. I., Al-Marzooqi, N. Y., \& Mohammed, Y. F. (2007). Organizational culture and knowledge sharing: Critical success factors. Journal of Knowledge Management, 11(2), 22-42. https://doi.org/10.1108/136732707107388 98

Alshehri, A., \& Cumming, T. M. (2020). Mobile technologies and knowledge management in higher education institutions: students' and educators' perspectives. World Journal of Education, 10(1), 12-22.

Biasutti, M., \& EL-Deghaidy, H. (2012). Using Wiki in teacher education: Impact on knowledge management processes and student satisfaction. Computers \& Education, 59(3), 861-872. https://doi.org/10.1016/j.compedu.2012.0 4.009

Blanchard, E. J., \& Olney, W. W. (2017). Globalization and human capital investment: Export composition drives educational attainment. Journal of International Economics, 106, 165-183. https://doi.org/10.1016/j.jinteco.2017.03.0 04

Blumberg, B., Cooper, D., \& Schindler, P. (2014). Ebook: Business research methods (4th ed.). McGraw Hill.

Bose, R. (2002). Knowledge management capabilities \& infrastructure for ecommerce. Journal of Computer Information Systems, 42(5), 40-49. https://doi.org/10.1080/08874417.2002.11 647608

Buckner, E. S. (2017). The changing discourse on higher education and the nation-state, 1960-2010. Higher Education, 74(3), 473-489. https://doi.org/10.1007/s10734016-0056-2

Burke, M. (2010). Overcoming challenges of the technological age by teaching information literacy skills. Community \& Junior College Libraries, 16(4), 247-254. https://doi.org/10.1080/02763915.2010.52 3327

Calantone, R. J., Cavusgil, S. T., \& Zhao, Y. (2002). Learning orientation, firm 
innovation capability, and firm performance. Industrial Marketing Management, 31(6), 515-524. https://doi.org/10.1016/S00198501(01)00203-6

Cheng, E. C. K. (2017). Knowledge management strategies for capitalising on school knowledge. VINE Journal of Information and Knowledge Management Systems, 47(1), 94-109. https://doi.org/10.1108/VJIKMS-08-20160045

Choi, B., Poon, S. K., \& Davis, J. G. (2008). Effects of knowledge management strategy on organizational performance: A complementarity theory-based approach. Omega, 36(2), 235-251. https://doi.org/10.1016/j.omega.2006.06.0 07

Chu, K. W., Wang, M., \& Yuen, A. H. K. (2011). Implementing Knowledge management in school environment: teachers' perception. Knowledge Management \& E-Learning: An International Journal, 3(2), 139-152. https://doi.org/10.34105/j.kmel.2011.03.0 13

Considine, D., Horton, J., \& Moorman, G. (2009). Teaching and reaching the millennial generation through media literacy. Journal of Adolescent \& Adult Literacy, 52(6), 471-481. https://doi.org/10.1598/JAAL.52.6.2

Davenport, T. H., \& Prusak, L. (1998). Working knowledge: How organizations manage what they know. Harvard Business Press.

Dinçer, S. (2018). Are preservice teachers really literate enough to integrate technology in their classroom practice? Determining the technology literacy level of preservice teachers. Education and Information Technologies, 23(6), 2699-2718. https://doi.org/10.1007/s10639-018-9737$\mathrm{z}$

Drucker, P. F. (2007). Management Challenges for the 21st Century. Routledge.

Dulipovici, A., \& Baskerville, R. (2007). Conflicts between privacy and property: The discourse in personal and organizational knowledge. The Journal of Strategic Information Systems, 16(2), 187-213.

https://doi.org/10.1016/j.jsis.2007.05.007
Easa, N. F. H. (2012). Knowledge management and the SECI Model: A study of innovation in the Egyptian Banking Sector [Dissertation, University of Stirling Stirling Management School]. http://dspace.stir.ac.uk/handle/1893/5053

Fornell, C., \& Larcker, D. F. (1981). Structural equation models with unobservable variables and measurement error: algebra and statistics. Journal of Marketing Research, 18(3), 382. https://doi.org/10.2307/3150980

Frenz, M., \& Ietto-Gillies, G. (2009). The impact on innovation performance of different sources of knowledge: Evidence from the UK Community Innovation Survey. Research Policy, 38(7), 11251135. https://doi.org/10.1016/j.respol.2009.05.0 02

Fuller, A., \& Unwin, L. (2004). Expansive learning environments: Integrating organizational and personal development. In Workplace Learning in Context (1st ed.). Routledge.

Goh, S. C. (2002). Managing effective knowledge transfer: An integrative framework and some practice implications. Journal of Knowledge Management, 6(1), 23-30. https://doi.org/10.1108/136732702104176 64

Gonzalez, R., \& Martins, M. F. (2017). Knowledge management process: A theoretical-conceptual research. Gestao e Producao, 24(22), 248-265. https://doi.org/10.1590/0104-530X089315

Griffin, P., \& Care, E. (Eds.). (2015). Assessment and teaching of 21st century skills. Springer Netherlands. https://doi.org/10.1007/978-94-017-93957

Henseler, J. (2017). Partial Least Squares Path Modeling. In P. S. H. Leeflang, J. E. Wieringa, T. H. A. Bijmolt, \& K. H. Pauwels (Eds.), Advanced methods for modeling markets (pp. 361-381). Springer International Publishing. https://doi.org/10.1007/978-3-319-534695_12

Hoegl, M., Parboteeah, K. P., \& Munson, C. L. (2003). Team-level antecedents of 
individuals' knowledge Networks*. Decision Sciences, 34(4), 741-770. https://doi.org/10.1111/j.15405414.2003.02344.x

Hogan, D., \& Gopinathan, S. (2008). Knowledge management, sustainable innovation, and pre-service teacher education in Singapore. Teachers and Teaching, 14(4), 369-384. https://doi.org/10.1080/135406008020377 93

Koenig, M. E. D., \& Srikantaiah, T. K. (Eds.). (2004). Knowledge management lessons learned: what works and what doesn't. Information Today Inc.

Lin, H. (2007). Knowledge sharing and firm innovation capability: An empirical study. International Journal of Manpower, 28(3/4), 315-332. https://doi.org/10.1108/014377207107552 72

Manfredo, M., Vaske, J., \& Teel, T. (2003). The potential for conflict index: a graphic approach to practical significance of human dimensions research. Human Dimensions of Wildlife, 8(3), 219-228. https://doi.org/10.1080/10871200304310

McDougall, J., Supa, M., van Driel, B., \& Sternadel, D. (2018). Teaching media literacy in Europe: Evidence of effective school practices in primary and secondary education (NESET II Report) [Analytic Report]. Publications Office of the European Union. https://doi.org/10.2766/613204

Nonaka, I., \& Takeuchi, H. (1995). The knowledge-creating company: How Japanese companies create the dynamics of innovation. Oxford University Press.

Pilgrim, J., \& Martinez, E. E. (2013). Defining literacy in the 21 st century: a guide to terminology and skills. Texas Journal of Literacy Education, 1(1), 60-69.

Rahim, F. R., Suherman, D. S., \& Murtiani, M. (2019). Analisis kompetensi guru dalam mempersiapkan media pembelajaran berbasis teknologi informasi era revolusi industri 4.0. Jurnal Eksakta Pendidikan (JEP), 3(2), 133-141. https://doi.org/10.24036/jep/vol3-iss2/367

Reid, F. (2003). Creating a knowledge-sharing culture among diverse business units.
Employment Relations Today, 30(3), 4349. https://doi.org/10.1002/ert.10097

Rusydiyah, E. F., Purwati, E., \& Prabowo, A. (2020). How to use digital literacy as a learning resource for teacher candidates in Indonesia. Cakrawala Pendidikan, 39(2), 305-318.

https://doi.org/10.21831/cp.v39i2.30551

Scheiner, T., Montes, M. A., Godino, J. D., Carrillo, J., \& Pino-Fan, L. R. (2019). What makes mathematics teacher knowledge specialized? offering alternative views. International Journal of Science and Mathematics Education, 17(1), 153-172. https://doi.org/10.1007/s10763-017-98596

Silamut, A., \& Petsangsri, S. (2020). Selfdirected learning with knowledge management model to enhance digital literacy abilities. Education and Information Technologies, 25(6), 47974815. https://doi.org/10.1007/s10639-02010187-3

Supermane, S. (2019). Transformational leadership and innovation in teaching and learning activities: The mediation effect of knowledge management. Information Discovery and Delivery, 47(4), 242-250. https://doi.org/10.1108/IDD-05-20190040

Suryandari, K. C., Sajidan, S., Rahardjo, S. B., Prasetyo, Z. K., \& Fatimah, S. (2018). Project-based science learning and preservice teachers' science literacy skill and creative thinking. Cakrawala Pendidikan, 37(3), Article 3. https://doi.org/10.21831/cp.v38i3.17229

Tan, C. N.-L., \& Noor, S. Md. (2013). Knowledge management enablers, knowledge sharing and research collaboration: A study of knowledge management at research universities in Malaysia. Asian Journal of Technology Innovation, 21(2), 251-276. https://doi.org/10.1080/19761597.2013.86 6314

Trilling, B., \& Fadel, C. (2009). 21st century skills: learning for life in our times. John Wiley \& Sons.

Voogt, J., \& Roblin, N. P. (2010). 21st century skills [Discussion article, University of Twente]. 
Zhao, J. (2010). School knowledge management framework and strategies: The new perspective on teacher professional development. Computers in Human Behavior, 26(2), 168-175. https://doi.org/10.1016/j.chb.2009.10.009
Zimmerman, A. S. (2008). New knowledge from old data: The role of standards in the sharing and reuse of ecological data. Science, Technology, \& Human Values, 33(5), 631-652. https://doi.org/10.1177/016224390730670 4 